Journal of Applied Biosciences 135: 13831 - 13839

ISSN 1997-5902

\title{
Distribution and incidence of Fusarium wilt in oil palm in Benin
}

\section{Claudine K. S. Laurentine KOUSSINOU*1,2 Appolinaire ADANDONON³ , Léifi NODICHAO ${ }^{1}$}

1 Center of Agricultural Research-Perennial Plants of Benin (CRA-PP / Pobè) of National Agricultural Researches Institute of Benin (INRAB). BP: N0 1-Pobè (Republic of Benin)

2 Research Unit of crop Biotechnology, Crop Protection, and Soil and Seed Sciences, Laboratory of crop Horticultural and Forestry Science of National University of Agriculture (Republic of Benin)

3 School of Crop and Seed Production and Management (EGPVS), National University of Agriculture of Benin (UNA) (Republic of Benin),

*Corresponding: Claudine KOUSSINOU*1,2, e-mail: claudinekoussinou057@gmail.com, phone: (+229) 94757554/96238102

Original submitted in on $9^{\text {th }}$ January 2019. Published online at www.m.elewa.org/journals/ on $31^{\text {st }}$ March 2019 https://dx.doi.org/10.4314/jab.v135i1.9

\begin{abstract}
Objectives: Fusarium wilt is the first oil palm pathology, who devastates the plantations in Africa. The currents study aims to diagnose the spatial distribution of this pathology and the incidence of the disease caused by Fusarium oxysporum elaeidis (Foe) in the palm oil growing zone of Benin.

Methodology and Results: Thus, a survey was carried out in May 2018 covering 16 plantations distributed in four agroecological zones of production of palm oil in Benin. In each plantation, 15 plants were randomly inspected to evaluate the incidence, the severity, and the distribution of the disease. Root and soil samples were collected at the foot of each evaluated tree, at a depth of $20 \mathrm{~cm}$ using an auger. Samples were stored in polyetilene bags, for the detection and isolation of the pathogenic agent. The results showed that incidence is significantly different depending on the agroecological zones prospected $(p=0.000)$. Central Cotton Zone (Kétou) and the Fisheries Zone (Adjohoun) recorded an incidence of vascular wilt of $0 \%$, whereas on the sites surveyed in the Depression Zone (Pobè, Adja-Ouèrè) and the Bar Land Zone (Ifangni, Missérété, Sakété, Adjarra) the recorded disease incidences were $30.0 \%$ and $12.5 \%$, respectively. This study also revealed an uneven distribution of the pathogen on the sites surveyed. Indeed, the study of the soil samples taken at the foot of the plants revealed that the presence of Foe does not systematically induce the disease, or induces it to varying levels, although the isolate is pathogenic and the material planted on each site is identical.

Conclusions and application of results: These results demonstrate a polymorphism of oil palm susceptibility to Fusarium wilt and underline the need to define a new screening approach based on the susceptibility factors of oil palm and which minimizes the intra-crossing variations observed.
\end{abstract}

Keywords: Fusarium oxysporum f. sp. elaeidis, incidence, severity, symptoms oil palms 


\section{INTRODUCTON}

Fungal diseases in oil palm are the major pathologies that cause significant yield losses in Africa (Diabaté, 2008). Vascular wilt is presently the most serious disease of the oil palm in West and Central Africa, particularly in Ivory Coast, Ghana, Benin, Nigeria, Cameroon and Congo Democratic Republic (Turner, 1981; Renard \& de Franqueville, 1989; Gogbe et al., 2017). Vascular wilt can cause up to $70 \%$ mortality in plantation (de Franqueville \& Renard 1990, Cochard et al., 2005). But with the new oil palm genotypes, its incidence diminishes. In 2016, vascular wilt disease incidence was recorded in many regions of Côte d'Ivoire including Dabou (0.87\%), Anguédédou $(0.60 \%)$, Divo $(0.48 \%)$, Ehania $(0.4 \%)$ and Grand Bereby (0.11\%) (Gogbe et al., 2017). The pathogenic fungus responsible of Fusarium wilt is, Fusarium oxysporum f. sp. elaeidis (Foe) (Fraselle, 1951). Foe infects the plant with root lesions, then migrates into the xylem vessels, causes a hormonal imbalance whose consequence is water stress (Flood, 2006). This physiological imbalance can lead to a decrease in production, and sometimes the death of the plant (Tengoua \& Bakoumé, 2008). (Renard \& Ravisé, 1986; Renard \& de Franqueville, 1989). The climate is also conducive to infection (Ho et al., 1985). Fusarium oxysporum $f$. sp. elaeidis infects all stages of palm growth, from seed to adult palm to seedlings in pre-nursery or nursery (Fraselle, 1951). However, there is a very remarkable difference between the expression of Fusarium wilt in the young plant and the adult oil palm (Renard \& Ravisé, 1986). In adult palm, two forms of phenotypic expression are observed depending on the typical or chronic

\section{MATERIALS AND METHOD}

Prospecting: The oil palm is grown in the southern region of Benin $\left(1^{\circ} 40-2^{\circ} 45 \mathrm{E}\right.$ and $6^{\circ} 20-7^{\circ} 45$ $\mathrm{N})$, (Fournier et al. 2001). The climate is a typical subequatorial with two rain seasons and two dry seasons. For this study the main region of oil palm production in Benin is chosen which falls into four agroecologicals and characterized by a diversity of soils and climatic parameters (table 1). In each district in these agroecological zones, two plantations established nature or disease. The chronic form is the persistent form of the disease in producing palms, while the typical form leads to plant death a few months after the onset of symptoms (Tengoua \& Bakoumé, 2008). The bases for phenotypic recognition of Fusarium wilt in oil palm have been established by Renard \& de Franqueville (1989). A typical form characterized by dehydration of the lower leaves and fracture of the spine by one-third from the petiole, slow growth and yellowing of the young leaves, and the chronic form resulting from a partial remission of typical symptoms. In this case the dry leaves fall and the palm tree emits two to four arrows which open only very slowly. The stipe narrows and evolves towards a point-like pencil appearance (de Franqueville \& Diabaté, 1995). On the other hand, in young palms, yellowing and then browning of an average leaf of the corona are first observed. This colouring then gains the neighbouring leaves of the same level, then the lower leaves (de Franqueville \& Diabaté, 1995). Internal symptoms include browning (discoloration of vessel walls and adjacent parenchyma) of xylem, which is characteristic of Foe (Cooper, 2011). The only way to control this disease in a sustainable plantation is planting of resistant material (Cooper, 2011). But Mepsted et al. (1994) indicated that there is a potential variability of Foe, and material developed in one area could succumb to infection elsewhere. This study aims to identify occurrence and distribution of the Fusarium wilt in the oil palm growing area in Benin and assess the incidence of the disease and its severity.

before 1995 and covering an area of 0.5 ha or more than 0.5 ha have been selected. In each plantation, a square of 0.5 ha was demarcated and 15 palm trees were haphazardly chosen. The occurrence (presence or absence of the symptoms) was noted. Severity of vascular wilt was evaluated by the chronology of the symptoms as described by de Franqueville \& Diabaté (1995), figure. The samples of roots and soil were taken by palm at a depth of $20 \mathrm{~cm}$ and deposited in 
polyethylene bags for detection and isolation of the pathogenic agent. The geographic coordinates of each site surveyed were recorded with a Garmin GPS.

Table 1: Characteristics of prospected zones

\begin{tabular}{|c|c|c|c|c|}
\hline Agroecological zones* & $\begin{array}{l}\text { Districts } \\
\text { surveyed }\end{array}$ & Soil types & Rainfall* $^{*}$ & Temperature* \\
\hline Central Cotton Zone & Kétou, & \multirow{4}{*}{$\begin{array}{l}\text { Along beach sandy } \\
\text { soil, red ferralitic, } \\
\text { vertic vertisols, } \\
\text { hydromorphic more } \\
\text { or less sandy or } \\
\text { clayey }\end{array}$} & $\begin{array}{c}1.000 \text { to } 1.300 \\
\mathrm{~mm}\end{array}$ & 26 to $38^{\circ} \mathrm{C}$ \\
\hline Depression Zone & $\begin{array}{l}\text { Pobè, Adja- } \\
\text { Ouèrè }\end{array}$ & & \multirow[t]{3}{*}{$\begin{array}{c}1.300 \text { and } 1.500 \\
\mathrm{~mm}\end{array}$} & \multirow[t]{3}{*}{25 to $35^{\circ} \mathrm{C}$} \\
\hline Fisheries Zone & Adjohoun, & & & \\
\hline Bar Land Zone & $\begin{array}{c}\text { Ifangni, } \\
\text { Missérété } \\
\text { Sakété Adjarra }\end{array}$ & & & \\
\hline
\end{tabular}

*DPP/MAEP (2001). *Azontonde (1991).

Foe detection test: In order to identify the presence of Foe in the soil in relation to the expression of phenotype symptoms, Foe was isolated from soil samples on MM culture media. Isolation of the pathogen had done on the mycelium medium according to the technique developed by Ntsefong-Ntsomboh et al. (2015). For this, the series of successive dilutions ($1-2-3$ ) at $1 / 10$ had done for $10 \mathrm{~g}$ of each soil sample after drying in the oven at $104{ }^{\circ} \mathrm{C}$ for 24 hours. The less diluted flasks (-3) were cultured in mycelium medium after autoclaved at $121^{\circ} \mathrm{C}$. for 15 minutes and distributed in plates sterilized at $200^{\circ} \mathrm{C}$ for 2 hours. Indeed $10 \mathrm{~g}$ of soil were introduced into a test tube containing $90 \mathrm{~mL}$ of distilled water. Then, $5 \mathrm{~mL}$ of the first dilution was introduced in $45 \mathrm{~mL}$ of distilled water. The flask was then covered with parafilm paper and agitated with a top mix (vortex) for 20 minutes for better suspension of micro-organisms and soil particles. Soil sample, only the most dulled flasks $(-3)$ were grown in order to avoid a very strong condensation of the microorganisms on the culture substrate. The culture media used were made up of the following composition: M Medium (Medium for Mycelium): $1 \mathrm{~g}$ dipotassium hydrogen phosphate, $0.5 \mathrm{~g}$ magnesium sulphate, $0.1 \mathrm{~g}$

\section{RESULTS}

Incidence by district: The table 2 below shows the percentage of plants showing phenotypically the symptoms of oil palm vascular wilt disease by districts. It shows that there is a very highly significant difference between the eight districts survey $(P=1.53 e-15)$. In iron sulphate, $1.5 \mathrm{~g}$ asparagine, $1 \mathrm{~g}$ yeast extract, $25 \mathrm{~g}$ Agar, $20 \mathrm{~g}$ glucose, $1 \mathrm{~L}$ distilled water. The pure cultures of the fungus are obtained by transferring on new media of 2-mm2 culture cut from mycelial growing edge of the isolates on culture media. Ten culture plates were done for each isolate, and identification was carried out based on microscopic characteristics (the nature of the mycelium, the morphology and formation of the conidiophore, the arrangement of conidia on conidiophores, the shape and size of conidia, the type and number of conidia) using identification keys developed by Booth (1971), figure 2.

Statistical analysis of the data: The incidence of the disease at each prospect site were calculated using the equation proposed by Cooke et al (2005):

$$
\mathrm{IM}=\mathrm{n} /(\mathrm{N}) \times 100
$$

With IM, the incidence of the disease on the site, $\mathrm{n}$, the number of plants on which the disease is present on the site, and

$\mathrm{N}$, the total number of plants observed on the site.

An analysis of variance followed by a classification was made for the incidence values per district in the software R 3.5.0. The distribution map of the vascular wilt in Benin was established.

fact, Adja-Ouèrè (36.67\%), Sakété $(50 \%)$ and Pobè $(23.33 \%)$ have vascular wilt, compared to other districts, where we haven't any vascular wilt infection $(0 \%)$. 
Table 2: Incidence by districts

\begin{tabular}{l|l}
\hline Districts & Foe infection $(\%)$ \\
\hline Adja-Ouèrè & $36.67 \pm 8.94_{\mathrm{bc}}$ \\
Adjarra & $0 \pm 0.00_{\mathrm{a}}$ \\
Adjohoun & $0 \pm 0.00_{\mathrm{a}}$ \\
Ifangni & $0 \pm 0.00_{\mathrm{a}}$ \\
Kétou & $0 \pm 0.00_{\mathrm{a}}$ \\
Missrété & $0 \pm 0.00_{\mathrm{a}}$ \\
Pobè & $23.33 \pm 7.85_{\mathrm{b}}$ \\
Sakété & $50 \pm 9.28_{\mathrm{c}}$ \\
F & 14.42 \\
$\mathbf{P}$ & 0 '***! \\
\hline
\end{tabular}

The values followed by the same small letters in the columns are not significantly different at $5 \%$ according to the Tukey test using R 3.5.0

Incidence by agroecological zones: Table 3 below shows the percentage of plants showing phenotypically the symptoms of oil palm vascular wilt disease by agroecological zones. It reflects a very highly significant difference between agroecological zones $(P=0.000)$. In fact, the sites surveyed in the Benin Central Cotton
Zone (Kétou) and the Fisheries Zone (Adjohoun) recorded an incidence of vascular wilt of $0 \%$, whereas on the sites surveyed in the Depression Zone (Pobè, Adja-Ouèrè) and the Bar Land Zone (Ifangni, Missérété, Sakété, Adjarra) we the incidences recorded were $30.00 \%$ and $12.50 \%$, respectively.

Table 3: Incidence by agro-ecological zones

\begin{tabular}{c|c}
\hline Agro-ecological zones(1) & Percentage of seedlings attacked(2) \\
\hline Central Cotton Zone & $0.00 \pm 0.000_{\mathrm{a}}$ \\
Depression Zone & $30.00 \pm 5.96_{\mathrm{b}}$ \\
Fisheries Zone & $0.00 \pm 0.000_{\mathrm{a}}$ \\
Bar Land Zone & $12.50 \pm 3.03_{\mathrm{c}}$ \\
F & $\mathbf{8 . 3 7 1}$ \\
$\mathbf{P}$ & $\mathbf{0 . 0 0 0}$ \\
\hline
\end{tabular}

The table 4 below shows the palm trees attacked per district the degree of infection and the presence of Foe in the soil samples taken at the foot of each tree. In the districts of Kétou, Adjarra, Ifangni, Missrété and Adjohoun, none of the trees tested showed the symptoms of vascular wilt, although the Foe pathogen was isolated from soil samples taken at the foot of these trees. In the district of Adja-Ouèrè, however, 11 trees were attacked against 19 phenotypically healthy trees, despite the homogeneity of the plant material planted and the presence of the pathogen at the foot of each tree. Similarly, we recorded the finding in the district of Pobè (7 of diseased plants and 23 of healthy plants), Sakété (15 of diseased plants and 15 of healthy plants). It pointed out that the fusarized trees showed a variability in the degree of infections. 
Table 4: Severity expression on oil palm according to district in Benin

\begin{tabular}{|c|c|c|c|c|c|c|}
\hline 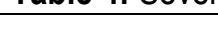 & 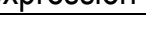 & Seve & y (de Franqueville \& Diaba & ,1995) & & \\
\hline District & $\begin{array}{l}\text { Trees } \\
\text { attacked }\end{array}$ & $\begin{array}{l}\text { Degree } 1 \text { : Desiccation of older } \\
\text { leaves and breaking of the } \\
\text { rachis near the base }\end{array}$ & $\begin{array}{l}\text { Degree } 2 \text { : Younger } \\
\text { fronds are then affected } \\
\text { successively and erect, } \\
\text { still green leaves } \\
\text { become reduced in size } \\
\text { and may become } \\
\text { chlorotic }\end{array}$ & $\begin{array}{l}\text { Degree } 3 \text { : The stipe narrows } \\
\text { and evolves towards a "pencil } \\
\text { tip" appearance }\end{array}$ & $\begin{array}{l}\text { Trees not } \\
\text { fusarized }\end{array}$ & $\begin{array}{c}\text { Presence of } \\
\text { Foe }\end{array}$ \\
\hline Kétou & 0 & - & - & - & 30 & Positive \\
\hline Adja-Ouèrè & 11 & & 11 & & 19 & Positive \\
\hline Pobè & 7 & 3 & 4 & - & 23 & Positive \\
\hline Adjarra & - & - & - & - & 30 & Positive \\
\hline Ifangni & - & - & - & - & 30 & Positive \\
\hline Missrété & - & - & - & - & 30 & Positive \\
\hline Sakété & 15 & - & 12 & 3 & 15 & Positive \\
\hline Adjohoun & - & - & - & - & 30 & Positive \\
\hline Total & 33 & 3 & 27 & 3 & 207 & - \\
\hline
\end{tabular}




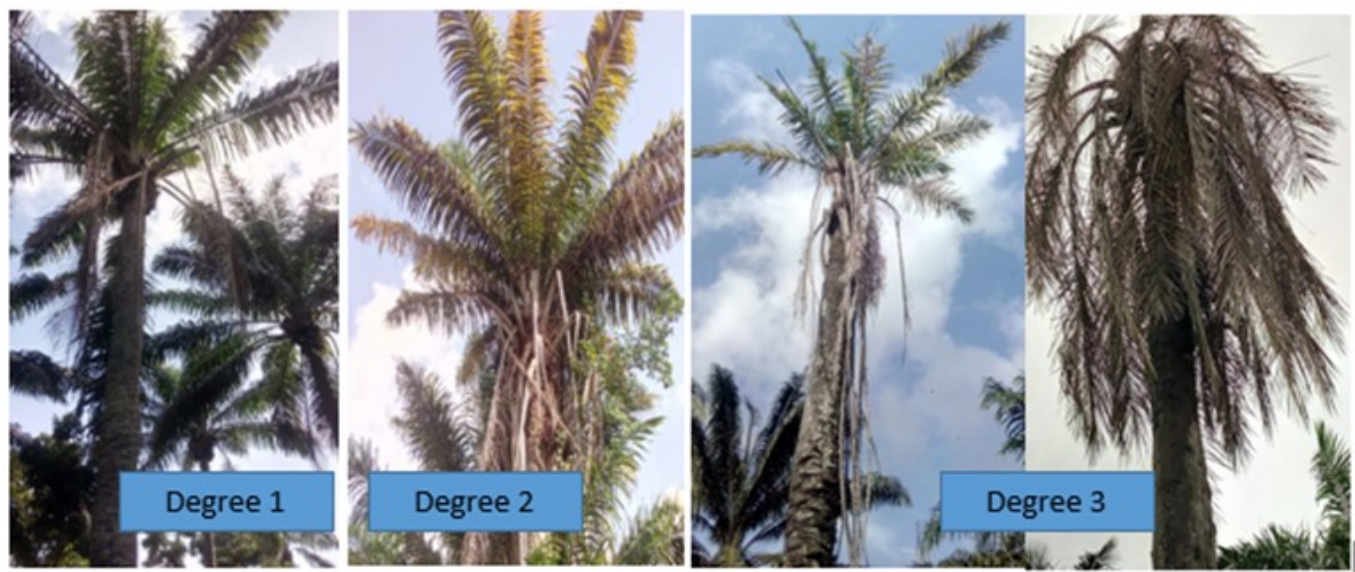

Figure 1: Palm plant showing the symptoms of vascular wilt in Benin

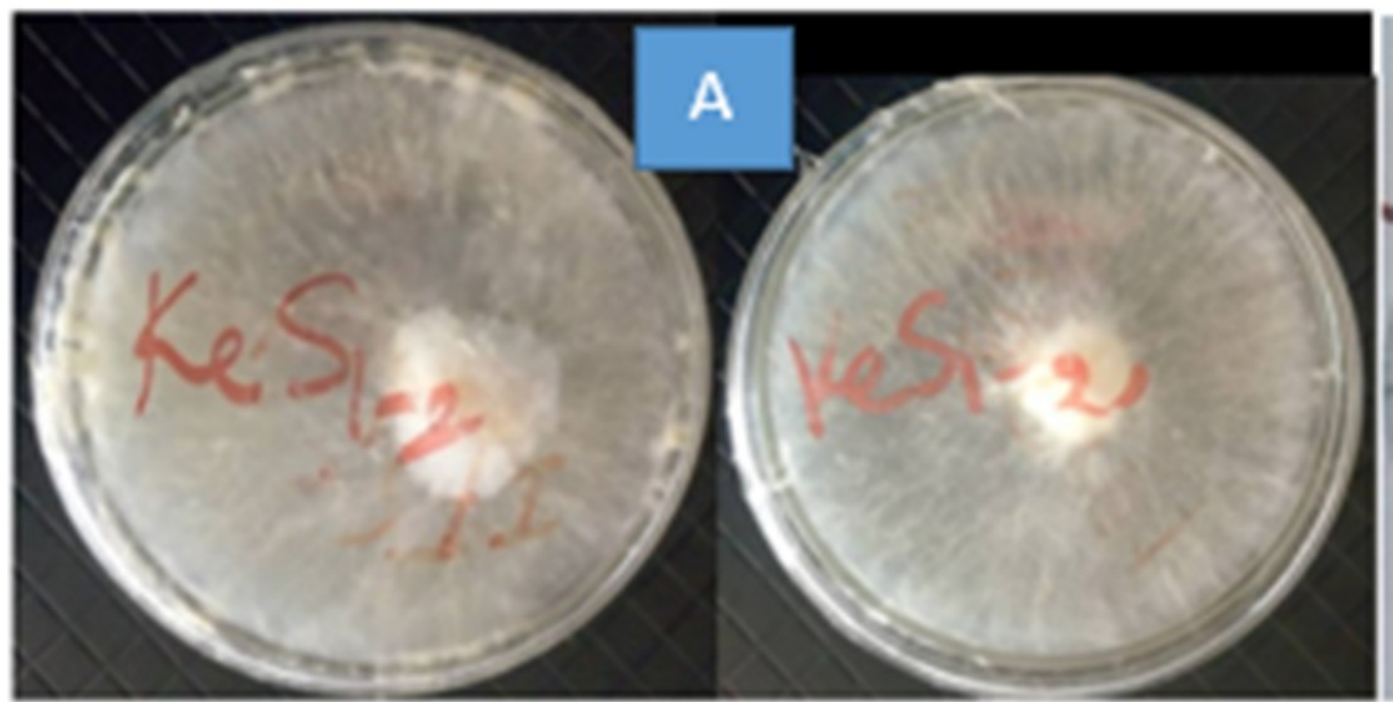

Figure 2: shows Foe on Mycelium Medium

Incidence per surveyed site: Vascular wilt was present in $25 \%$ of sites (4 out of 16 sites) surveyed in Benin. The sites were grouped into four classes of incidence, materialized by different colorations. Figure 3 below shows the incidence map by surveyed site. On this map two sites, the site of Ahita (Sakété) and Kokorokein (Adja-Ouèrè) recorded the highest incidence value ( $S>55 \%$ ). These sites are the most vulnerable to vascular wilt. 


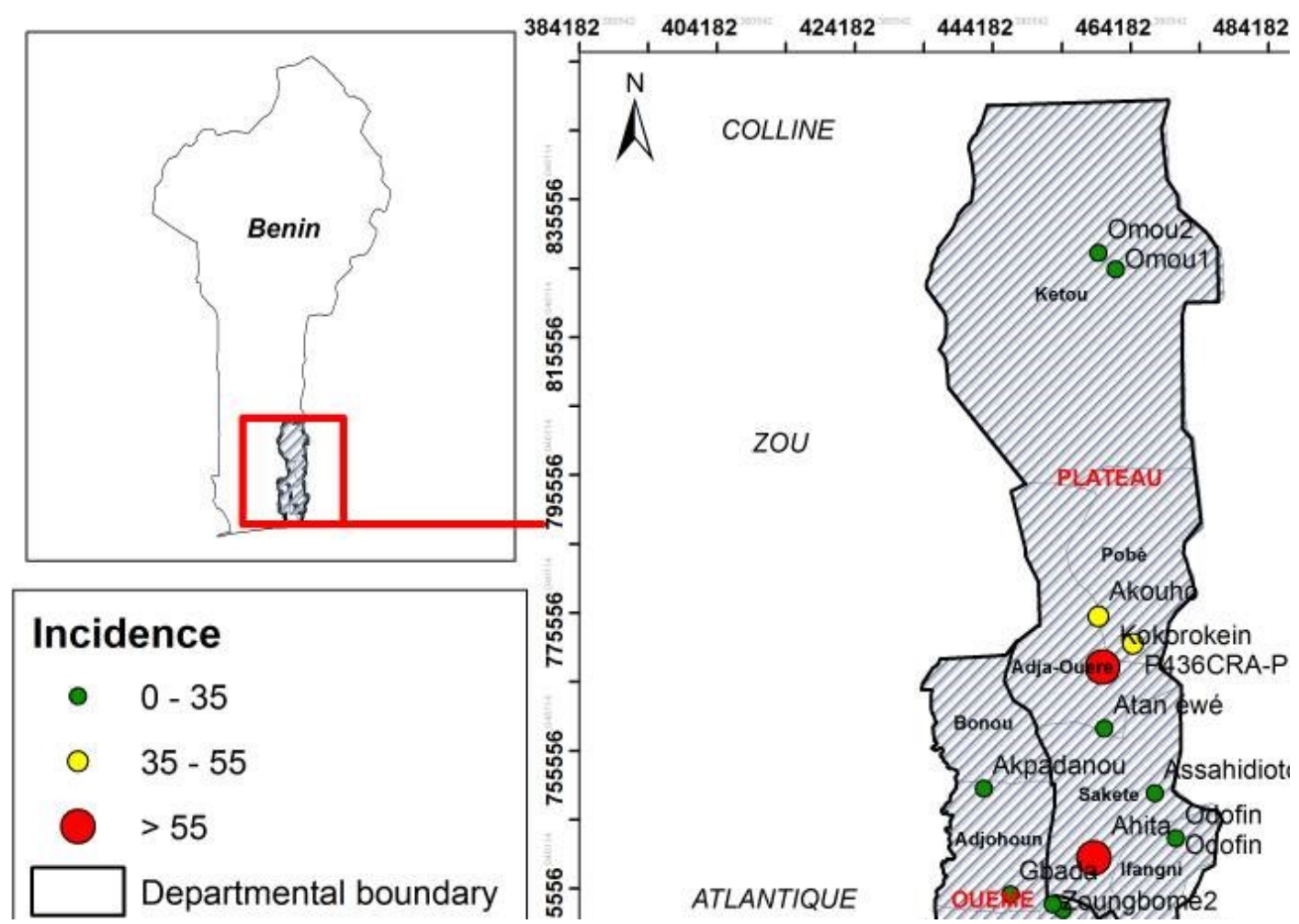

Figure: 3 Map showing incidence of vascular wilt by site surveyed in 2018

Class 1: 0-15\%, Class 2: $15-35 \%$, Class 3: $35-55$, Class 4 :> 55\%.

\section{DISCUSSION}

The average incidence varied from site to site and ranged from $0.00 \%$ to $50 . \%$. The highest incidence values were obtained at Sakété, Adja-ouèrè, and Pobè districts. This means that these sites harbour spread strains of Fusarium oxysporum elaeidis and that the plant material is susceptible to vascular wilt. However, although the analysis of the soil samples taken at the foot of each plant revealed the presence of Foe at the different sites, and that the plant material was homogeneous by site, all the plants present did not phenotypically manifest vascular wilt. This indicates a variability in the expression of vascular wilt. This could be due to the differential responses of the same gene cluster or to the expression of different groups of genes (Cockerhan, 1963; Falconer, 1990). Indeed, Meunier (1979) has established that the tolerance to vascular wilt is of polygenic type. So we know that the establishment of the infection depends on specific and sophisticated recognition mechanisms, called the genefor-gene reaction between the plant and the pathogen (Flor, 1971). In addition, the development of infection is conditioned by the interactions between pathogen effectors and host susceptibility genes (Chetouhi, 2015). In oil Palm, tolerance to vascular wilt is associated with tissue accumulation of inhibitory substances for $F$. oxysporum, whose synthesis depends on the lineage genome, and to a lesser extent individual variability, (Taquet, 1985). This could suggest the polymorphic nature of the genes involved in the establishment of vascular wilt in oil palm with impact, a polymorphism of palm susceptibility to vascular wilt. This finding confirms the results obtained, in prenursery in Ivory Coast by Dixon et al. (1981), Whitehead al. (1982), Lawton et al. (1983). These authors found the same plasticity when studying the individual variability between plants from the same cross. The variability of susceptibility to vascular wilt observed in individuals from the same genetic population could help to define a new pre-nursery screening approach based on oil palm susceptibility factors and the modalities of defense mechanisms on adult plants. 


\section{CONCLUSION}

The survey shows that incidence of Vascular wilt is significantly different depending on the agroecological zones. This study also revealed a non-homogeneous distribution of the pathogen on the sites surveyed. Indeed, the study of the soil samples taken at the foot of the plants revealed that the presence of Foe does

\section{ACKNOWLEDGMENTS}

This work was financed and has received technical supports from the Center of Agricultural Research

\section{BIBLIOGRAPHY}

Azontondé HA, 1991. Propriétés physiques et hydrauliques des sols au Bénin. Soil Water. Balance in the Sudano-Sahelian Zone. Proceedings of the Niamey Work Shop. International Association of Hydrological Sciences 199: 253-256.

Booth C, 1971. The Genus Fusarium: Laboratory Guide to the Identification of the Major Species. The Common Wealth Mycological Institute, Kew, Surrey. $237 \mathrm{pp}$.

Chetouhi C, 2015. Bases moléculaires de la sensibilité du blé tendre (Triticum aestivum) à la fusariose de l'épi causée par le champignon Fusarium graminearum. Sciences agricoles, Universite Blaise Pascal - Clermont-Ferrand II. Français, Thèse de doctorat.325 pp.

Cochard B, Amblard P, Durand-Gasselin T, 2005. Oil palm genetic improvement and sustainable development. Oléagineux, Corps gras, Lipides 12 (2): 141-145.

Cockerhan FBA, 1963. Clinical and experimental. The Australian Journal of Optometry 46: 33-36.

Cooke BM, Jones DG, Kaye B, 2005. Disease assessment and yield loss. In: The epidemiology of plant diseases. 2nd Edn, Springer, Netherlands, 43-80.

Cooper RM, 2011. Fusarium wilt of oil palm: A continuing threat to South East Asian Plantations. The Planter 87(1023): 409 -418.

de Franqueville $\mathrm{H}$, and Renard JL, 1990. Improvement of oil palm vascular wilt tolerance. Results and development of the disease at the R. Michaux plantation. Oleagineux 45: 399-405.

de Franqueville $\mathrm{H}$, et Diabaté S, 1995. La fusariose du palmier à huile en Afrique de l'Ouest. Plantations, recherche et développement. 5-10 p. not systematically induce the disease, or induces it to varying levels, despite the isolate present is pathogenic and the material planted on each site is identical. This remark results in a polymorphism in the expression of the disease by the plants.

perennial plants (CRA-PP), National Institute of Agricultural Research of Benin (INRAB).

Diabate S, 2008. Contribution à l'étude de la diversité phénolique dans la réaction de défense du palmier à huile (Elaeis guineensis jacq) contre la fusariose vasculaire. Thèse de Doctorat de I'Université de Cocody (Abidjan). 155 pp.

Dixon RA, Dey PM, Murphy DL, Witehead LM, 1981. Dose responses for Colletotrîcnum lindemutliianum elicitor mediated enzyme induction $\mathrm{fm}$. french bean cell suspension cultures. Planta 151: 272-280.

Falconer DS, 1990. Selection in different environments: effects on environmental sensitivity (reaction norm) and on mean performance. Cambridge University Press 56 (38): 57-70.

Flood J, 2006. A review of Fusarium wilt of oil palm caused by Fusarium oxysporum f.sp. elaeidis. Phytopathology 96: 660-662.

Flor $\mathrm{HH}, 1971$. Current status of the gene-for-gene concept. Annual Review of Phytopathology 9:275-296.

Fournier S, Okounlola-Biaou A, Adjé Al, 2001. L'importance des filières locales: le cas de I'huile de palme au Bénin. Oléagineux, Corps Gras et Lipides 8 (6): 646-653.

Fraselle JV, 1951. Experimental evidence of the pathogenicity of Fusarium oxysporum Schl. $f$. to the oil palm (Elaeis guineensis J.). Nature 167 (4246), 447.

Gogbe BF, Diabate S, Konan J-N, Kablan K, Dogbo DO, 2017. Oil palm Fusarium wilt distribution and incidence in Southern Region of Ivory Coast. African Journal of Agricultural 12(39): 2895-2901.

Ho YW, Varghese G, Taylor GS, 1985. Pathogenicity of Fusarium oxysporum isolates from Malaysia and $F$. oxysporum f. sp. elaeidis from Africa to seedlings of oil palms (Elaeis guineensis). Phytopathology 114: 193-202. 
Lawton MA, Dixon K, Lamb CJ, 1982. Rapid induction of PAL and chalconesynthetase synthesis in elicitor treated plant cells. European Journal of Biochemistry 129: 593-596.

MAEP, 2001. Ministère de l'Agriculture de l'Elevage et de la Pêche. Direction de la Planification et de la Prospective. Carte des zones agroécologiques du Bénin.

Mepsted R, Flood J, Paul T, Cooper RM, 1994. Virulence and aggressiveness in Fusarium oxysporum f. sp. elaeidis; implications for screening for disease resistance. Oleagineux 49: 209-212.

Meunier J, Renard JL, et Quillec G, 1979. Hérédité de la résistance à la fusariose chez le Palmier à huile Elaeis guineensis. Oléagineux 34: 555561.

Ntsomboh-Ntsefong G, Madi G, Nyaka NA, Nsimi MA, Epoh NT, Kato SN, Lum AF, Ngando EG, 2015. Vascular wilt disease tolerance status of some oil palm (Elaeis guineensis Jacq.) progenies in relation to local strains of Fusarium oxysporum f. sp. Elaeidis in Cameroon. International Journal of Current Research in Biosciences and Plant Biology 2 (8): 111-122.

Renard JL, 1979. La fusariose du Palmier à huile. Diagnostic en plantation. Méthodes de lutte. Oléagineux 34: 58-63.

Renard JL, Ravise A, 1986. La fusariose du palmier à huile. Phytoma 374: 44-46.

Renard JL, de Franqueville H. 1989. Oil palm vascular wilt. Oléagineux 44(7):341-349.

Taquet B, 1985. Les mécanismes physiologiques de la réaction de défense du palmier à huile ( $E$. guineensis Jacq.) contre la fusariose vasculaire. Application et la recherche de nouveaux moyens de lutte. Thèse de Doctorat de 3 c cycle, Paris VI.164 pp.

Tengoua FF, Bakoumé C, 2008. Pathogenicity of Cameroon strains of Fusarium oxysporum $f$. $s p$. elaeidis - the causal agent of oil palm vascular wilt. The Planter 84 (985): 233-237.

Turner PD, 1981. Oil palm diseases and disorders. Oil palm diseases and disorders. Oxford University Press. Kuala Lumpur Malaysia.280 pp.

Whiteheal M, Deyaud M, Dixon R, 1982. Differential patterns of phytoalexin accumulation and enzyme induction in wounded and elicitor treated tissues of Phaseolus vulgaris. Planta 154: 156-164. 